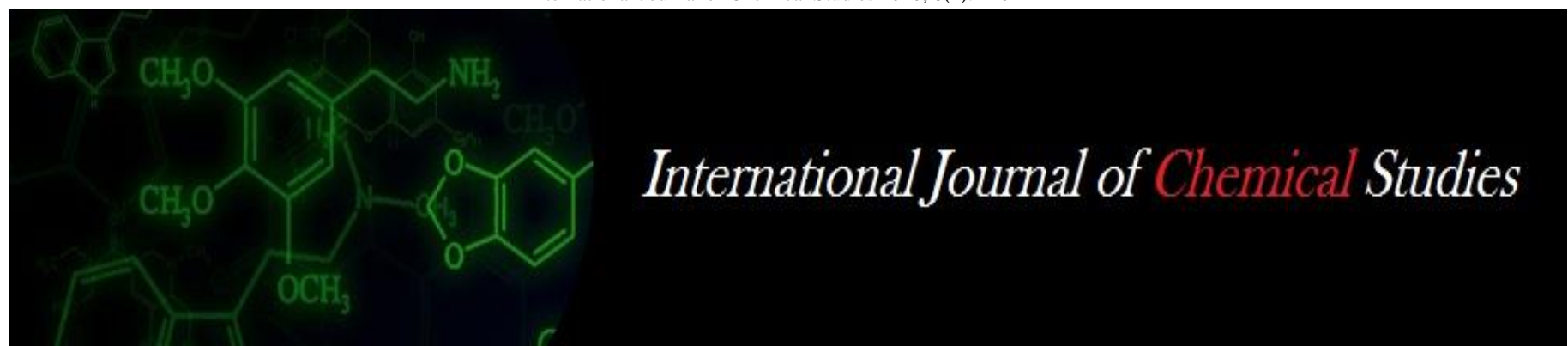

P-ISSN: 2349-8528

E-ISSN: 2321-4902

IJCS 2020; 8(1): 420-424

(C) 2020 IJCS

Received: 13-11-2019

Accepted: 17-12-2019

Basave Gowda

National Seed Project Crops,

Seed Unit, University of

Agricultural Sciences, Raichur,

Karnataka, India

Umesh Hiremath

Department of Seed Science and

Technology, University of

Agricultural Sciences Raichur,

Karnataka, India

Vinod Kumara

Department Of Seed Science and

Technology, UAS, Raichur,

Karnataka, India

\section{Ganiger BS}

Seed Unit, University of

Agriculture Sciences, Raichur,

Karnataka, India

Shanta C Matti

Seed Unit, University of

Agriculture, Sciences, Raichur,

Karnataka, India
Corresponding Author:

Basave Gowda

National Seed Project Crops,

Seed Unit, University of

Agricultural Sciences, Raichur,

Karnataka, India

\section{Effect of seed treatment with fungicides on seed quality of soybean (Glycine max L.) during storage}

\author{
Basave Gowda, Umesh Hiremath, Vinod Kumara, Ganiger BS and Shanta \\ C Matti
}

DOI: https://doi.org/10.22271/chemi.2020.v8.i1f.8283

\begin{abstract}
A laboratory experiment was conducted to study the effect of fungicides on seed vigour and viability of soybean. The experiment was laid out in completely randomised block design with six treatments that included different fungicide solutions at different concentrations and was replicated four times. The results revealed that, among the various seed treatments, the seeds treated with sprint (Mancozeb 50\% + Carbendazim 25\% WS) @ $3 \mathrm{~g} \mathrm{~kg}^{-1}$ recorded significantly highest seed quality parameters viz., seed germination, total seedling length, seedling dry weight, seedling vigour index, seed infection and lower electrical conductivity compared to all other treatments and the lowest was recorded in the absolute control. Hence soybean seeds treated with Sprint (Mancozeb 50\% + Carbendazim 25\% W S) @ $3 \mathrm{~g} \mathrm{~kg}^{-1}$ of seeds enhanced seed quality parameters during storage.
\end{abstract}

Keywords: Soybean, sprint, seed treatment

\section{Introduction}

One of the basic needs in agriculture is quality seed. Quality seed is characterised by high viability and vigour. These two characters cannot be differentiated in storage, especially in seed lots of crop species like soybean (Glycine max L. Merr.) that rapidly deteriorate under ambient storage in subtropical and tropical environments, with high temperatures. Soybean (Glycine $\max$ L.) is also known as boneless or vegetable meat due to its high nutritious cotyledons acting as important component in balanced diet. Its seeds account for about 56 per cent of global oilseed production and highly quoted on the world market (Wilson, 2008) ${ }^{[35]}$. The crop is generally designated as golden or miracle crop due to high nutritive value and exploited for vegetable oil extraction for human consumption (Hymowitz, 1981) ${ }^{\text {[13] }}$. It has been considered as a single large source for vegetable oil extraction, economically feasible in India. It is regarded as legume cum oilseed crop due to 40-42 per cent protein and 20-22 per cent oil content making it as viable option for oil extraction.

Soybean being an oilseed crop has recalcitrant nature, hence cannot retain viability for longer periods. Seed deterioration is faster in soybean than other crops (Priestley et al., 1985) ${ }^{[25]}$.

Loss of seed viability and vigour in any crop is a natural phenomenon which is inexorable, irreversible and inevitable associated with genetic, physical, physiological and biochemical factors besides storage environment, such as prevailing relative humidity, temperature, pest and diseases etc., which are known to cause both qualitative and quantitative loss. Exposure to warm, moist air, typical of the humid tropical regions, is principally responsible for this. To arrest seed deterioration in storage, therefore, dry-cold conditioned storage structures are recommended, which are, however, expensive $(\mathrm{Ng}, 1988)^{[23]}$. In the search for cheaper alternatives, seed treatments with broad-spectrum fungicides such as thiram and carboxin hold promise. They are not only effective against a wide range of pathogens (Subramanya et al., 1988) ${ }^{[32]}$, but also are thought to delay seed deterioration during storage (Shekaramurthy et al., 1994) ${ }^{[28]}$. This will also help in assessing the physiological changes during storage (Daniel, 1997; Daniel et al., 1999) [6,7], which may be variable for different genotypes. Seed borne infection or infected seed is very important discouraging factor, which possess a serious 
problem in seed certification. Although infected seeds which may otherwise be viable with prescribed Germinability as per certification standards, many times it may not be acceptable as seed because of poor physical appearance, high incidence of seed borne fungi and mycotoxin such as aflatoxin.

Hence, an experiment was conducted to elucidate the effect of seed treatment with different fungicides on seed quality of soybean seeds during storage.

\section{Material and Methods}

The soybean seeds of variety DSb21 were collected from the Agriculture Research Station, Bidar and the laboratory experiment was carried out in the Seed Research and Quality Assurance Laboratory, Seed Unit, University of Agricultural Sciences, Raichur. The treatment details includes six treatments viz., $\mathrm{T}_{0}$ : Control (Absolute control), $\mathrm{T}_{1}$ : Thiram @ $2 \mathrm{~g} \mathrm{~kg}^{-1}, \mathrm{~T}_{2}$ : Captan @ $2 \mathrm{~g} \mathrm{~kg}^{-1}, \mathrm{~T}_{3}$ : Sprint (Mancozeb 50\%+ Carbendazim 25\% W S) @ $3 \mathrm{~g} \mathrm{~kg}^{-1}, \mathrm{~T}_{4}$ : Vitavax power (Carboxin 37.5\% + Thiram 37.5\%) @ 2 $\mathrm{g} \mathrm{kg}^{-1}, \mathrm{~T}_{5}$ : Xelora (Thiophanate Methyl 45\% + Pyraclostrobin 5\% FS) @ 2.5ml $\mathrm{kg}^{-1}$ and the treated seeds were shade dried overnight to safe moisture level and packed in cloth bags to be used for assessment of seed quality parameters during storage at monthly interval.

Germination test was conducted using 100 seeds by between paper method where seeds were placed between germination papers and incubated in the walk in seed germination room. Germination percentage, seedling length and seedling dry weight was calculated on $8^{\text {th }}$ day and expressed in percentage (ISTA, 2014) ${ }^{[14]}$. The seedling vigour index-I was worked out by multiplying the per cent germination and total seedling length (Abdul-Baki and Anderson, 1973) ${ }^{[1]}$. Seed infection percentage is calculated by counting number of seeds that showed prevalence of fungal growth in petri plate after $8^{\text {th }}$ day of incubation $\left(25 \pm 2{ }^{\circ} \mathrm{C}\right.$ under diurnal conditions) of seeds.

Electrical conductivity of the seed leachate was measured in the digital conductivity bridge (WENSAR) with a cell constant 1.0 and the mean values were expressed in deci Siemens per meter $\left(\mathrm{dSm}^{-1}\right)$ (Milosevic et al. 2010). The OD value of dehydrogenase enzyme activity was obtained as reported by Kittock and Law (1968) ${ }^{[17]}$.

\section{Results and Discussion}

Seed deterioration is an unavoidable process and it could be slowed down either by storing the seeds under controlled conditions or by imposing certain treatments with either chemicals or any other protectants. So, certain fungicides were used in this experiment to determine their effect on seed vigour and viability. In this experiment fungicides like Thiram, Captan, Vitavax power (Carboxin 37.5\% + Thiram $37.5 \%$ ), Sprint (Mancozeb 50\% + Carbendazim 25\% W S) and Xelora (Thiophanate Methyl 45\% + Pyraclostrobin 5\% FS) were used. Thiram is used as a fungicide, ectoparasiticide to prevent fungal diseases in seed and crops. Captan is manmade fungicide used to control a range of fungal diseases. Vitavax power is a specialized seed treatment fungicide for effective control and prevention of diseases present externally and within the seeds with increased level of disease control and gives combinational effect of carboxin and thiram on disease control. Sprint controls the seed and soil borne diseases of crops caused by Ascomycetes, Basidiomycetes, Imperfect fungi and Oomycetes group of fungi in early stages. Xelora used as seed dressing fungicide and mainly controls the diseases caused by root rot fungi (Rhizoctonia Spp).
In this experimental study, seeds treated with fungicides exhibited significant differences for seed quality parameters. Seeds treated with sprint (Mancozeb 50\% + Carbendazim $25 \%$ WS) recorded highest seed germination $(79.75 \%)$ as compared to control $(69.25 \%)$. The higher germination percentage seen in seeds treated with fungicides is due to increase in the rate of imbibition where the fine particles in the coating act as moisture attracting material to improve germination. The polymer coat on seed acts as a physical barrier that has been reported to reduce leaching of inhibitors from the seed coverings and may restrict oxygen diffusion to the embryo (Duan and Burris, 1997) ${ }^{[10]}$ and also Struve and Hopper (1996) [31] reported that cotton seeds coated with polymer recorded slower imbibition rate, reduced the imbibition damage, lowered the electrical conductivity values and thus improved the germination. This increase in seed germination might be due to reduced incidence of seed-borne fungal pathogens compared to control. The polymer keeps the seed intact, as it acts as binding material and covers the minor cracks and aberrations on the seed coat thus blocking the fungal invasion. Similar results were observed by Venkatesh et al. (2018) ${ }^{[33]}$ in Soyabean and Ashwini and Giri (2014) ${ }^{[4]}$ in green gram. The reduction in seed germination over time could also be linked to the reduction in enzyme activity within the seed and with the reduction in seed germination percentage; there is reduction in all the seed quality parameters [Ruzrokh et al. (2003) ${ }^{[26]}$, and Demirkaya et al. (2010) $]^{[8]}$.

Higher total seedling length and seedling dry weight were significantly higher in treated seeds compared to untreated seeds, this may be due to the influence of seed treatment with different fungicides. Higher seedling length $(33.25 \mathrm{~cm})$ and seedling dry weight $(612.00 \mathrm{mg})$ observed by seeds treated with sprint compared to untreated seeds $(27.70 \mathrm{~cm}$ and 538 $\mathrm{mg}$, respectively). This may be due to proper supply of water and nutrients and reflected by reducing the seed infection by pathogen and due to induction of photosynthesis and synthesis of $\alpha$ - amylase, protease and other hydrolytic enzymes which appear to induce the activity of gluconeogenic enzymes during early stage of seed germination cause lengthy seedling and also higher 100 seed weight directly correlated with the higher seedling length. Lower seedling length and dry weight in control during storage may be attributed to ageing effects, leading to depletion of food reserves and decline in synthetic activity of the embryo apart from death of seeds because of fungal invasion (Gupta et al., 1993) ${ }^{[11]}$. These findings are in agreement with results obtained by Hunje et al. (1990) ${ }^{[12]}$ in cowpea. This might be due to the influence of residual systemic action of zinc and manganese present in sprint which contributed in increasing the metabolic activity of enzymes that helped in excess cell division, enlargement and elongation of root length, making root surface to absorb more nutrient from media and also easier for plumule meristem to grow with elongation and enlargement of shoot cells. These are probable reasons for increased germination root and shoot length. The results are in confirmation with the findings of Seema (2017) ${ }^{[27]}$ in Kabuli chickpea and Anitha et al. (2013) ${ }^{[2]}$ in soybean.

Seeds treated with sprint (Mancozeb 50\% + Carbendazim $25 \% \mathrm{WS}$ ) recorded highest seedling vigour index (2651.7) as compared to control (1918.2). This can be attributed to the reason that seeds treated with sprint recorded highest germination percentage, total seedling length and also seedling dry weight, thus seedling vigour index was high. A positive and significant correlation was observed between 
germination percentage and vigour index. Fungicides inhibited fungal growth and improved seedling vigour (Zote and Mayee, 1982) ${ }^{[36]}$. Similar findings were observed by Khatun et al. (2009a) ${ }^{[16]}$.

The results also showed that lowest seed infection $(2.00 \%)$, seed moisture content $(7.95 \%)$ and electrical conductivity $\left(0.480 \mathrm{dSm}^{-1}\right)$ were recorded by seeds treated with sprint as compared to untreated seeds $\left(7.25 \%, 8.29 \%\right.$ and $0.541 \mathrm{dSm}^{-1}$, respectively). The moisture fluctuation was more in untreated seeds compared to treated seeds because when seeds are treated with chemicals it covers the pores in the seed coat and prevents the entry of both water and fungal mycelia and provide protection from physical damage which can occur during handling and storage (West et al., 1985) ${ }^{\text {[34] The }}$ results are in accordance with the findings of Meena et al. (1998) ${ }^{[20]}$ and Shivayogi et al. (2009) ${ }^{[30]}$ in cotton. The seed infection was lowest in treated seeds compared to control because treated seeds help in inhibiting the growth of fungi which might be due to the fungicidal effect on production of pectolytic and cellulolytic enzymes by the fungi and thereby reducing the incidence of fungal pathogen (Mehta et al., 1990) ${ }^{[21]}$. Similar findings were reported by Kathiravan et al. (2008) ${ }^{[15]}$ in lablab and Shivagouda et al. (2014) ${ }^{[29]}$ in pigeonpea. The lower electrical conductivity was recorded in treated seeds over untreated seeds which may be due to fungicide that protects the seeds from storage pathogens and thus reduces the seed infection, cracks and aberrations of the seed coat and also the leaching of electrolytes. These results are in agreement with Maheshbabu and Ravi Hunje (2008) ${ }^{[19]}$ in soybean; Basave Gowda et al. (2018) ${ }^{[5]}$ in chickpea and Patil (2000) in chickpea. Desai et al. (1997) ${ }^{[9]}$ reported that high frazzle increases the membrane damage, disturbance of certain enzyme activity responsible for degradation of macromolecules into micro molecules within the seed and other cell structures and thus higher electrical conductivity in untreated seeds. In non-viable seeds, there is reduced activity of enzymes such as dehydrogenase, $\alpha$ - amylase and catalase, which can contribute significantly to the reduction of respiratory activity. Ageing in wheat was in association with accumulation of hydrogen peroxide (Lehner et al., 2008) ${ }^{[18]}$. The results of this study concluded that seeds treated with Sprint (Mancozeb 50\% + Carbendazim 25\% W S) @ $3 \mathrm{~g} \mathrm{~kg}^{-1}$ fungicide recorded highest seed quality parameters in storage compared to untreated seeds and seeds can be stored up to 9 months without reducing seed viability and vigour.

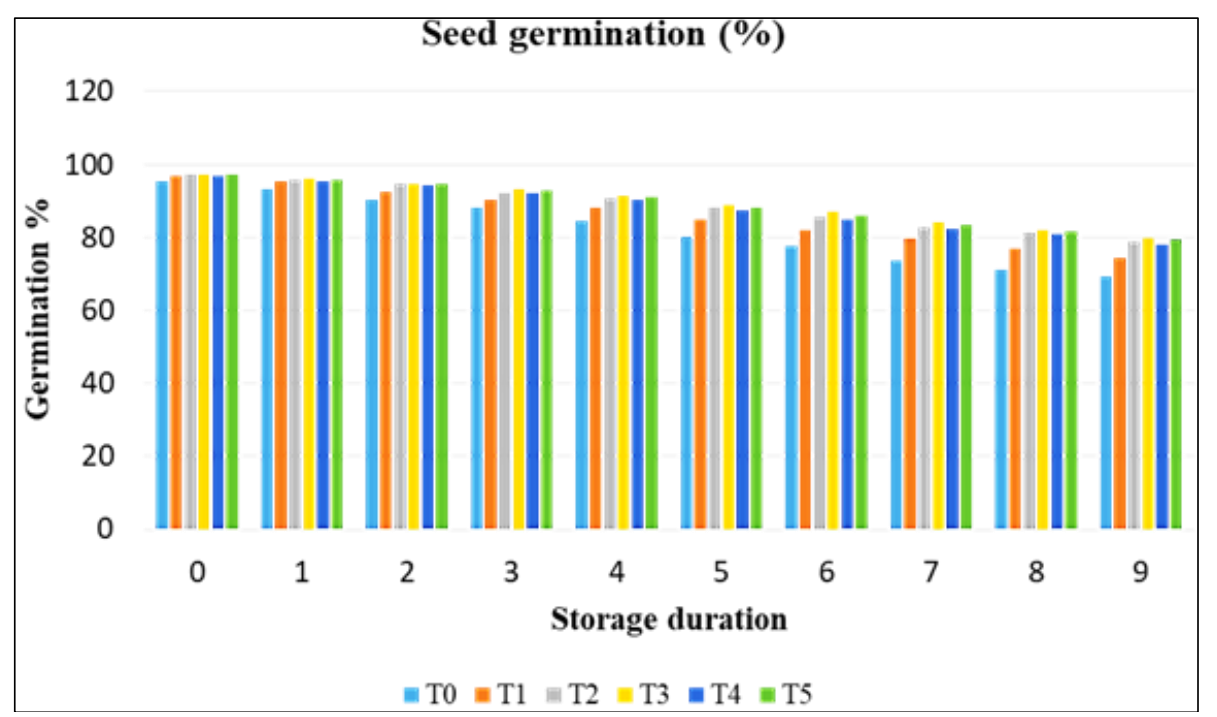

Fig 1: Effect of seed treatment with different fungicides on seed germination (\%) of soybean during storage

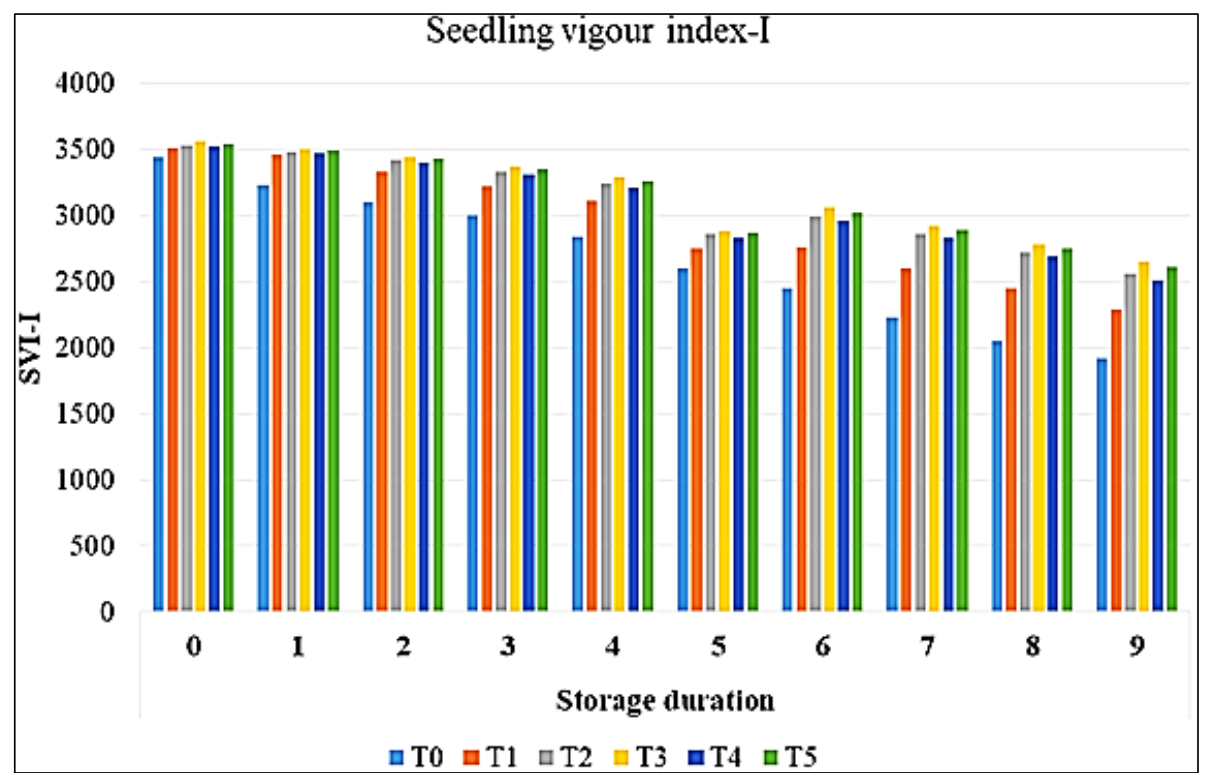

Fig 2: Effect of seed treatment with different fungicides on seed vigour index-I of soybean during storage 


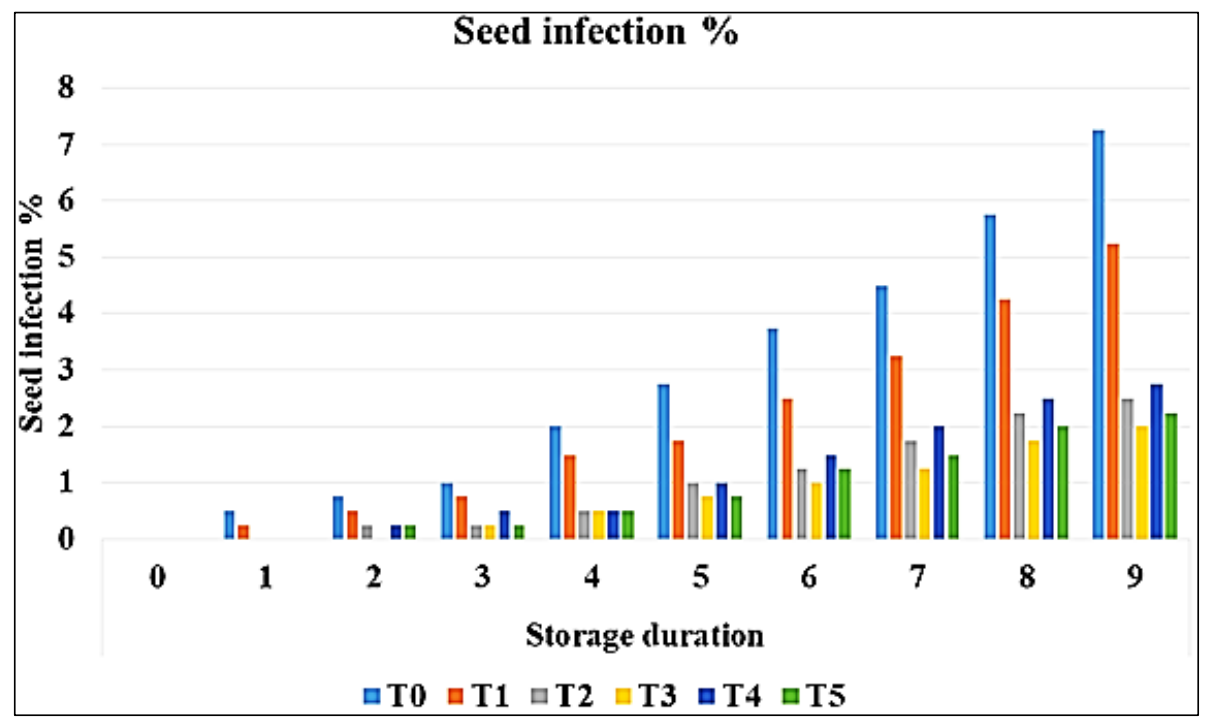

Fig 3: Effect of seed treatment with different fungicides on seed infection (\%) of soybean during storage

\section{References}

1. Abdul-Baki AA, Anderson JD. Vigour determination in soybean seed by multiple criteria. Crop sci. 1973; 13(6):630-633.

2. Anitha U, Mummigatti V, Punith Kumar CH., Effect of organic and inorganic seed priming on soybean germination and yield parameters. Bio life. 2013; 1(4):2330 .

3. Anonymous. International Rules for Seed Testing. Seed Sci. Tech. 2014; 44(2):27-32.

4. Ashwini C, Giri GK. Detection and transmission of seed borne mycoflora in green gram and effect of different fungicides. Int. J Adv. Res. 2014; 2(5):1182-1186.

5. Basave Gowda, Bhemanna H, Arunkumar H, Rakesh CM, Raghu BN, Rekha. Effect of organics in enhancing seed storability of chickpea (Cicer arietinum L.). Int. J Chemical Studies. 2018; 6(2):1890-1893.

6. Daniel IO. Conservation of West African yam (Dioscorea spp.) germplasm: Physiology of seed and pollen storage. PhD Thesis, University of Ibadan, Nigeria, 1997, 148.

7. Daniel IO, Ng NQ, Tayo TO, Togun AO. West African yam seeds stored under cold and desiccated conditions are orthodox. Seed Sci. Technol. 1999; 27:969-975.

8. Demirkaya M, Dietz KJ, Sivritepe HO. Changes in antioxidant enzymes during aging of onion seeds. Notulae Botanicae Horti. Agrobotanici. 2010; 38(1):49-52.

9. Desai BB, Kotecha PM, Shalunke DK. Seed hand bookBiology, Production, Processing and Storage. Marcel Dekker. Inc. New York. 473-496, 1997.

10. Duan X, Burris JS. Film coating impairs leaching of germination inhibitors in sugar beet seeds. Crop Sci. 1997; 37:515-520.

11. Gupta IJ, Schmitthenner AE, McDonald MB. Effect of storage fungi on seed vigour of soybean. Seed Sci. Tech. 1993-1997; 21:581-591.

12. Hunje RV, Kulkarni GN, Shashidhara SD, Vyakaranahal BS. Effect of insecticide and fungicide treatment on cowpea seed quality. Seed Res. 1990; 18:90-92.

13. Hymowitz T, Newell CA. Taxonomy of the genus Glycine, domestication and uses of soybeans. Eco. Bot. 1981; 35(3):272-288.

14. ISTA. International rules for seed testing. Seed Sci. and Technol., Supplement rule. 2014; 27:27-31.

15. Kathiravan M, Vijayakumar A, Vanitha C. Effect of dry dressing treatments and containers on seed quality parameters in lablab (Lablab purpureus L.) under natural ageing conditions. Indian J Agric. Res. 2008; 42(1):62-66.

16. Khatun A, Kabir G, Bhuiyan MAH. Effect of harvesting stages on the seed quality of lentil (Lens culinaris L.) during storage. Bangladesh J Agril. Res. 2009a; 34(4):565-576.

17. Kittock DL, Law AG. Relationship of Seedling Vigor to Respiration and Tetrazolium Chloride Reduction by Germinating Wheat Seeds. Agronomy Journal. 1968; 60(3):286-8.

18. Lehner A, Mamadou N, Come D, Bailly C, Corbineau F. Changes in soluble carbohydrates, lipid peroxidation and antioxidant enzyme activities in the embryo during ageing in wheat grains. J Cereal Sci. 2008; 47:555-565.

19. Maheshbabu HM, Ravi H. Effect of seed treatment with botanicals on storability of soybean. Karnataka J Agric. Sci. 2008; 21(3):357-360.

20. Meena RA, Rathinavel RK, Deshmukh RK, Tuteja OP. Storage potential of tetraploid and diploid cottons under ambient conditions. Seed Res. 1998; 27(1):125-127.

21. Mehta A, Chopra, Mehta P. Fungicide's inhibitory agent of cell wall degrading enzymes. J Indian Phytopathology. 1990; 43:117-120.

22. Milosevic MM, Vujakovic D, Karagic. Vigour tests as indicators of seed viability. Genetica. 2010; 42(1):103118.

23. Ng NQ. Long-term seed conservation. In: Proceedings of International Conference on Crop Genetic Resources of Africa, Kenya, 1988, 135-148.

24. Patil SK, Tanpure SV, Shelar VR, Dumbre AD. Efficacy of insecticides and fungicides on seed germination, insect infestation and seed mycoflora on pearl millet during storage. Seed Res. 2002; 32(2):189-192.

25. Priestley DA, Cullinan VI, Wolfe J. Differences in seed longevity at the species level. Plant Cell Environ. 1985; 8:557-562.

26. Ruzrokh M, Golozani KG, Javanshir A. Relation between seed vigour with growth and yield in pea (Cicer arietinum L.). Nahal o Bazr. 2003; 18:156-169.

27. Seema Beedi, Basave Gowda, Sangeeta I, Macha Savitha AS, Vijaykumar Kurnallikar. Effect of seed priming on germination percentage, shoot length, root length, seedling vigour index, moisture content and electrical conductivity in storage of Kabuli chickpea $c v$. MNK-1 (Cicer arietinum L.). J Pharma. Phytochemistry. 2017; 7(1):2005-2010. 
28. Shekaramurthy SK, Patkar L, Shetty SA, Prakash HS, Shetty HS. Effect of Thiram treatment on sorghum seed quality in relation to accelerated ageing. Seed Sci. Technol. 1994; 22:607-617.

29. Shivagouda P, Rajendra P, Bharamraj B, Yegappa H, Maruthi K, Shankrayya. Impact of seed treatment chemicals on seed storability in pigeon pea (Cajanus cajan (L.) mill sp.). J Life Sci. 2014; 9(3):985-989.

30. Shivayogi R, Biradar PNK, Girredi RS, Katageri IS. Effect of acid delinting seed treatment and containers on storability of cotton hybrid. Karnataka J Agric. Sci. 2009; 22(1):56-60.

31. Struve TH, Hopper WT. The effect of polymer film coating on cotton seed imbibition, germination and emergence. Proceedings of Belt wide Cotton conference, Nashville, TN, USA. 1996; 2:1167-1170.

32. Subramanya KN, Prakash HS, Shetty HS, Karanth NGK. Effect of Thiram and Bastin on sorghum seeds stored under different conditions. Pesticides. 1988; 22:25-27.

33. Venkatesh B, Basave Gowda, Vasudevan SN, Doddagoudar SR, Gururaj Sunkad, Konda CR. Effect of seed coating with fungicides along with polymer on seed storability of soybean (Glycine $\max$ L. Merril). International Journal of Chemical Studies. 2018; 6(5):598602.

34. West SH, Loftin SK, Wahl M, Batich, Beatty CL. Polymer and seed treatment as a moisture barrier to maintain seed quality. Crop Sci. 1985; 25:941-944.

35. Wilson RF. Soybean: Market driven research needs: Genetics and genomics of soybean. Springer Science, New York, 2008.

36.Zote KK, Mayee CD. Influence of fungicidal seed treatment during storage on seed-borne fungi of mungbean. Pesticides. 1982; 16(4):10-12. 